УДК 330

\title{
ОПТИМИЗАЦИЯ БИЗНЕС-ПРОЦЕССОВ В СФЕРЕ ОБСЛУЖИВАНИЯ В УСЛОВИЯХ ПАНДЕМИИ
}

Батукаева Анжела Руслановна старший преподаватель кафедры «Бизнес-информатика»

Хасаева Аминат Абуевна

студент

ФГБОУ ВО «Чеченский государственный университет имени Ахмата Абдулхамидовича Кадырова»

Аннотация: Рассмотрена важная и актуальная тема проблем бизнеспроцесса обслуживания во время пандемии Covid-19, затронувшей все сферы общества. Внимание уделяется примерам дифференцированных компаний и корпораций, которые до пандемии вели смешанный бизнес, и их действия описываются с точки зрения эффективной оптимизации. Сделаны подробные выводы о шагах, которые компании должны предпринять для поддержания прибыльности своего бизнеса, включая последовательность, отношение к болезням, безопасность, а также методы продаж и изменения в поведении потребителей.

Ключевые слова: пандемия, анализ, исследование, изменения, трансформация.

\section{OPTIMIZATION OF BUSINESS PROCESSES IN THE SERVICE SECTOR IN THE CONTEXT OF A PANDEMIC}

Batukaeva A.R.

Khasaeva A.A.

\begin{abstract}
An important and relevant topic of the problems of the business process of service during the Covid-19 pandemic, which affected all spheres of society, is considered. Attention is paid to examples of differentiated companies and corporations that conducted mixed business before the pandemic, and their actions are described from the point of view of effective optimization. Detailed conclusions
\end{abstract}




\section{ЭКОНОМИКА, УПРАВЛЕНИЕ, ПРАВО: АКТУАЛЬНЫЕ ВОПРОСЫ И ВЕКТОРЫ РАЗВИТИЯ}

are drawn about the steps that companies should take to maintain the profitability of their business, including consistency, attitude to diseases, safety, as well as sales methods and changes in consumer behavior.

Key words: pandemic, analysis, research, change, transformation.

\section{Введение}

Пандемия коронавируса 2020 года продолжает оказывать существенное воздействие на финансовую и хозяйственную жизнедеятельность как компаний, так и государства в целом. Она стала своего рода «стимулятором» к реинжинирингу традиционной деятельности компаний. Поэтому данная тема и до сих пор остается крайне актуальной, в связи с тем, что болезнь еще не «сдалась» и большинство компаний продолжают «борьбу» с негативными последствиями, оказанными на их бизнес-процессы [3].

Для тех хозяйствующих субъектов, которые сейчас находятся не в лучшей форме, очень важно начать сокращать затраты сейчас, перейти на удаленную работу, а также оптимизировать все управленческие решения. Специалистами Банка РФ была проведена оценка, исходя из источника «Обзор финансовой стабильности. IV квартал 2019 - I квартал 2020 г.» [2], коллапс 2020 года оказался внезапным настолько, что затрудняет возможность определится с методикой решения проблемы выхода из данного коллапса. Проведенные исследования показали, что больше $50 \%$ российских компаний перешли на систему удаленной работы. Более $80 \%$ работодателей считают, что такая система утвердится и будет оказывать стратегическое воздействие на бизнес, весомо изменив критерии ее работы. Диверсифицированные организации данный процесс переживают гораздо легче, так как в их структуру уже внедрены онлайн форматы, которые могут развиваться пока оффлайн, находится в заморозке.

\section{Какие же компании можно считать диверсифицированными?}

Характерным примером такой компании является Яндекс. Она активно использовала онлайн режим еще задолго до первых проявлений пандемии. Сервис включает такие направления как: «Яндекс.Драйв» - это доступная поминутная аренда автомобилей, «Яндекс.Еда» - доставка готовой еды, «Яндекс.Карты» и многое другое. После того, как ввели карантин компания столкнулась с запретом на систему аренды автомобилей, в результате чего на стоянке остались офлайн-мощности в виде сотен машин, не участвующих ни в 


\section{ЭКОНОМИКА, УПРАВЛЕНИЕ, ПРАВО: АКТУАЛЬНЫЕ ВОПРОСЫ И ВЕКТОРЫ РАЗВИТИЯ}

каком бизнес-процессе и причиняющих компании убытки. Корпорация смогла быстро трансформировать процессы в текущих условиях, в том числе функцию доставки товаров и продуктов населению в службах такси, поскольку такси не было запрещено. Наличие мощных ресурсов (карты, пробки) позволяло отслеживать уровень самоизоляции населения, фактически помогая властям контролировать ситуацию.

Такими же примерами являются компании-ритейлеры: X5 Retail Group, «Магнит», «Дикси», «Лента» и др. Благодаря хорошей оснащенности основными средствами каждая из компаний смогла организовать быструю доставку товаров клиентам, минимально понеся убытки. Такие маркетплейсы, как «Озон» и «Wildberries», которые и так вели свою финансово-хозяйственную деятельность в онлайн режиме, прошли ряд трансформаций в своих бизнеспроцессах, а именно: была убрана возможность примерки товаров, а также существенно сокращено количество доступных пунктов выдачи. С апреля по июнь аудитория покупателей «Wildberries», по словам представителя ритейлера, выросла примерно на 6 миллионов и достигла 30 миллионов зарегистрированных пользователей.

\section{Каковы должны быть действия бизнеса в таких условиях?}

Со стороны системности [1] необходимо условно разделить процессы на 3 части: острые вопросы, срочные вопросы, долгосрочные вопросы. Каждый момент требует назначения ответственного руководителя, который будет контролировать все бизнес-процессы. Все системы подвержены высокой нагрузке, важно поэтапно ее снижать. А именно:

$\checkmark$ внедрить системы работы удаленно: корпоративное программное обеспечение, безопасность, обучение персонала системе инструментов корпоративной коммуникации;

$\checkmark$ не бросать коммуникацию с действующими клиентами: осуществить оперативное информирование любым доступным способом, если бизнеспроцессы временно приостановлены;

$\checkmark$ продумать информационную безопасность. Отслеживать, чтобы переход на новый формат работы был безопасен для данных.

Со стороны отношения к заболеваемости, глобальная цель государства и бизнеса - снизить заболеваемость. В современных условиях бизнес должен думать не только о сохранении структуры компании; очень важно работать над сдерживанием болезни. Регулярное тестирование на коронавирус, а также на 
антитела к нему и своевременная вакцинация персонала помогут плавно снять существующие ограничения, реанимируя бизнес [4].

Со стороны продаж важно понимать, что любая кризисная или резонансная ситуация может спровоцировать процесс изменения поведения потребителей. Пандемия 2020 года не исключение; Компаниям необходимо учиться и адаптироваться к привычкам, чтобы привлекать новых клиентов и удерживать внимание старых.

\section{Заключение}

Подводя итог, отметим, что пандемия в большинстве случаев стала отправной точкой для развития новых технологий, медицины, информационных технологий и управления персоналом. Преобразование старых бизнес-процессов важно, потому что другого способа сохранить компанию нет. Компания должна быть ориентирована на изменения и реагировать, чтобы не терять своих клиентов. Только совместными усилиями и тонким анализом можно будет уловить тренд и остаться на плаву.

\section{Список литературы}

1. Алтуфьева Н.В. Влияние цифровизации на развитие малых предприятий / Н.В. Алтуфьева // Инновации в менеджменте, 2020, №23, с. 4-9.

2. Обзор финансовой стабильности. IV квартал 2019 - I квартал 2020г. // Сайт Банка России. [Электронный ресурс]. - URL: http://cbr.ru/ Collection/Collection/File/27911/OFS_20-01.pdf, (дата обращения: 02.01.2022)

3. Влияние коронавируса COVID-19 на экономику России // Сайт TAdviser.ru. [Электронный pecypc]. - URL: https:/www.tadviser.ru/ index.php/Статья:Влияние_коронавируса_COVID19_на_экономику_России\#.D0 .А2, (дата обращения: 02.01.2022)

4. Как трансформировать бизнес-стратегию в период пандемии, А. Ахвердян, электронный журнал «Эксперт», // Сайт expert.ru. [Электронный pecypc]. - URL: https://expert.ru/2020/06/16/kak-transformirovat-biznes-strategiyuv-periodpandemii/, (дата обращения: 02.01.2022)

(C) А.А. Хасаева, А.Р. Батукаева,2022 